\title{
Off-treatment durability of antiviral response to nucleoside analogues in patients with chronic hepatitis $B$
}

Naruhiko Nagata, Tatehiro Kagawa*, Shunji Hirose, Yoshitaka Arase, Kota Tsuruya, Kazuya Anzai, Koichi Shiraishi and Tetsuya Mine

\begin{abstract}
Background: Off-treatment durability of nucleoside analogue (NA) therapy in patients with chronic hepatitis B has not been well investigated. In this study we monitored antiviral effect of NA therapy and evaluated off-treatment durability after NA cessation in patients with chronic hepatitis B.

Patients and methods: A total of 94 consecutive patients (39 HBeAg-negative and 55 HBeAg-positive patients) who received NA therapy were followed up for approximately 9 years. We discontinued NA according to the following criteria; undetectable serum HBV-DNA by polymerase chain reaction (PCR) on three separate occasions at least 6 months apart in HBeAg-negative patients (APASL stopping recommendation), and seroconversion from HBeAg-positive to HBeAb-positive and undetectable serum HBV-DNA by PCR for at least 12 months in HBeAg-positive patients.

Results: The cumulative rate of relapse after NA cessation was $48 \%$ and $40 \%$ in HBeAg-negative and -positive patients, respectively. Higher baseline serum alanine aminotransferase level was the only significant predictor for maintaining remission. No patients experienced decompensation after relapse. HBsAg loss occurred at an annual rate of $1.4 \%$ and $0.4 \%$ in HBeAg-negative and -positive patients, respectively. Hepatocellular carcinoma developed at an annual rate of $0.6 \%$ in both HBeAg-negative and -positive patients.

Conclusions: Almost half of the patients did not relapse after cessation of NA therapy in both HBeAg-negative and -positive patients. Therefore, NA therapy could be discontinued with close monitoring if the APASL stopping recommendation is satisfied even in HBeAg-negative patients.
\end{abstract}

Keywords: Chronic hepatitis B, Nucleoside analogue, Durability, Hepatocellular carcinoma, HBs antigen

\section{Background}

Nucleoside analogues (NAs) are shown to improve prognosis of patients with chronic hepatitis B. Continuous treatment with lamivudine (LMV) delayed clinical progression defined by hepatic decompensation, hepatocellular carcinoma (HCC), spontaneous bacterial peritonitis, bleeding gastroesophageal varices, or liver disease-related death in patients with chronic hepatitis B and advanced fibrosis or cirrhosis [1]. NAs can suppress hepatic inflammation by inhibiting viral proliferation in most cases, however, this effect is transient. Relapse after NA cessation

\footnotetext{
*Correspondence: kagawa@tokai.ac.jp

Division of Gastroenterology and Hepatology, Department of Internal Medicine, Tokai University School of Medicine, Shimokasuya 143, Isehara 259-1193, Japan
}

(c) 2016 Nagata et al. Open Access This article is distributed under the terms of the Creative Commons Attribution 4.0 International License (http://creativecommons.org/licenses/by/4.0/), which permits unrestricted use, distribution, and reproduction in any medium, provided you give appropriate credit to the original author(s) and the source, provide a link to the Creative Commons license, and indicate if changes were made. The Creative Commons Public Domain Dedication waiver (http://creativecommons.org/publicdomain/zero/1.0/) applies to the data made available in this article, unless otherwise stated. (ALT) flare with 10 times higher than normal upper limit was reported in up to $20 \%[2,3]$ of patients who discontinued NA treatment. These results suggest that NA discontinuation should be decided with caution. On the other hand, considerable number of patients are receiving NA treatment even if they actually no longer need NA. Therefore, making a discrimination of patients who can discontinue NA treatment is important from the viewpoint of health care economics.

Currently there is no clear consensus on when to stop NA treatment. For HBeAg-negative patients, the guidelines from the American Association for the Study of Liver Diseases (AASLD) [10] and the European Association for the Study of the Liver (EASL) [11] recommend 
long-term NA treatment until HBsAg seroclearance has been achieved. Although HBsAg seroclearance is an ideal goal of NA treatment, it takes place in only a minority of patients $(<1 \%$ per year [10]). On the other hand, the Asian-Pacific Association for the Study of the Liver (APASL) guideline [12] suggests that treatment discontinuation can be considered if patients have been treated for at least 2 years with undetectable HBV-DNA documented on three separate occasions 6 months apart, even if $\mathrm{HBsAg}$ seroclearance is not achieved. For HBeAgpositive patients, the AASLD, EASL and APASL guidelines recommend that NA treatment can be discontinued when $\mathrm{HBeAg}$ seroconversion with undetectable HBVDNA has been maintained for 6-12 months.

There have been several studies on off-treatment durability of NA's antiviral effect (see review [13]), however, the results considerably vary by study. Therefore, the accumulation of further data is required.

In this study we monitored antiviral effect of NA therapy and evaluated off-treatment durability after NA cessation according to the APASL stopping recommendation in patients with chronic hepatitis B.

\section{Methods}

We consecutively enrolled the patients who started treatment with LMV or entecavir (ETV) from December 1999 through June 2010. Most patients started with ETV since ETV was approved in Japan (July 2006). These patients were positive for serum HBsAg and HBV-DNA, and had elevated ALT at least twice before initiating treatment. We excluded patients who were coinfected with HCV or HIV, and those with liver cirrhosis or HCC. We discontinued NA treatment after obtaining verbal informed consent when patients satisfied the APASL stopping recommendation [12]; undetectable serum HBV-DNA by polymerase chain reaction (PCR) on three separate occasions at least 6 months apart in HBeAg-negative patients, and seroconversion from $\mathrm{HBeAg}$-positive to $\mathrm{HBeAb}$-positive and undetectable serum HBV-DNA by PCR for at least 12 months in HBeAg-positive patients. Treatment for at least 2 years was not a prerequisite for NA discontinuation in this study. Patients were followed up every one to three months to monitor blood chemistry and HBV markers. They received ultrasonography for the surveillance of HCC every 6 months. Relapse after NA discontinuation was defined as serum ALT elevation more than twice the upper limit of normal or serum HBV-DNA elevation higher than $5 \log c o p y / m L$ at 2 consecutive examinations. Serum HBV-DNA levels were measured by COBAS TaqMan HBV test (Roche Molecular Systems, Inc., Pleasanton, $\mathrm{CA}$ ). Serum HBsAg was quantitated by Architect assay (Abbott Japan, Co., Ltd., Tokyo, Japan). A part of serum samples were stored at $-80^{\circ} \mathrm{C}$ until measurement. This study had been approved by Institutional Review Board for Clinical Research, Tokai University Hospital, and was performed in accordance with the Declaration of Helsinki.

\section{Statistical analysis}

Pearson chi-square and Fisher exact probability tests were performed to compare the frequency distributions of categorical variables between groups. One-way analysis of variance was used to test the differences in means between groups for continuous variables. The probabilities of satisfying NA discontinuation criteria, relapse, disappearance of serum HBsAg, and progression to HCC were estimated using the Kaplan-Meier method, and differences between groups were compared using the log-rank test. Analyzed baseline factors included age, gender, HBV genotype, serum ALT, HBV-DNA, HBsAg, and liver histology assessed by METAVIR classification [14]. The factors with $P$ value $<.1$ by univariate analysis were evaluated with a Cox proportional hazards regression model. All statistical analyses were performed using SPSS version 22 (SPSS Japan, Tokyo, Japan). All reported $P$ values are 2-sided, with $P<.05$ considered statistically significant.

\section{Results}

\section{Patient characteristics}

The cohort consisted of 94 patients; 39 and 55 patients were negative and positive for $\mathrm{HBeAg}$, respectively (Table 1 ). The HBeAg-negative patients were significantly older than the HBeAg-positive patients. Most patients were infected with genotype C HBV (84\% and $97 \%$ in HBeAgnegative and -positive patients, respectively). The serum HBV-DNA levels were significantly higher in the HBeAg-positive patients. The mean \pm SD of the followup period was $108 \pm 42$ (min-max: 18-182) and $111 \pm 42$ (min-max: 16-178) months in HBeAg-negative and -positive patients, respectively.

\section{Outcome of the patients HBeAg-negative patients}

Twenty-five $(64 \%)$ patients received LMV, while the remaining 14 (36 \%) received ETV (Fig. 1). Most of the patients $(23 / 25,92 \%)$ receiving LMV met the APASL stopping recommendation. Of 23 patients 17 agreed to stop LMV treatment, and 10 of these 17 patients (59\%) maintained remission. In 7 patients who relapsed, 3 achieved remission afterwards and 4 started ETV treatment. All of 14 patients $(100 \%)$ receiving ETV met the stopping criteria. Six of 14 patients agreed to stop ETV treatment, and 2 of 6 (33\%) maintained remission. In 4 relapsers, 2 achieved remission afterwards, and 2 restarted ETV. The mean \pm SD of NA treatment duration until discontinuation was $40 \pm 41$ (min-max: 8-141) and $26 \pm 17$ (minmax: 9-50) months in patients who received LMV and 
Table 1 Patient characteristics

\begin{tabular}{|c|c|c|c|c|c|}
\hline \multirow[t]{2}{*}{ Variables } & \multicolumn{2}{|c|}{ HBeAg (-) (n=39) } & \multicolumn{2}{|c|}{$\operatorname{HBeAg}(+)(n=55)$} & \multirow[t]{2}{*}{$P$ value } \\
\hline & no. & $\%$ & no. & $\%$ & \\
\hline Age, $<40 / 40-59 / 60 \leq$ & $7 / 22 / 10$ & $18 / 56 / 26$ & $22 / 23 / 10$ & $40 / 42 / 18$ & 0.07 \\
\hline Age (y/o) & $50.0 \pm 11.8$ & & $44.3 \pm 14.5$ & & 0.03 \\
\hline Gender, female/male & $11 / 28$ & $28 / 72$ & $18 / 37$ & $33 / 67$ & 0.7 \\
\hline Drug, LAM/ETV & $25 / 14$ & $64 / 36$ & $38 / 17$ & $69 / 31$ & 0.7 \\
\hline $\operatorname{ALT}(I U / L),<100 / 100-199 / 200 \leq$ & $12 / 16 / 11$ & $31 / 41 / 28$ & $20 / 13 / 22$ & $36 / 24 / 40$ & 0.19 \\
\hline HBV-DNA (Log copy/mL), <6/6-7.6/7.6< & $11 / 22 / 6$ & $28 / 56 / 15$ & $4 / 20 / 31$ & $7 / 36 / 56$ & 0.001 \\
\hline Genotype*, B/C & $5 / 26$ & $16 / 84$ & $1 / 37$ & $3 / 97$ & 0.07 \\
\hline HBsAg $(\mathrm{IU} / \mathrm{mL})^{*},<1000 / 1000-10000 / 10000 \leq$ & $7 / 11 / 5$ & $30 / 48 / 22$ & $3 / 9 / 8$ & $15 / 45 / 40$ & 0.09 \\
\hline Histology (METAVIR Staging)*, 1/2/3 & $13 / 8 / 6$ & $48 / 30 / 22$ & $11 / 13 / 7$ & $35 / 42 / 23$ & 0.6 \\
\hline Histology (METAVIR Grading)* 1/2/3 & $7 / 17 / 3$ & $26 / 63 / 11$ & $8 / 15 / 8$ & $26 / 48 / 26$ & 0.3 \\
\hline
\end{tabular}

*Data were not available in some patients

ETV, respectively. The difference between LMV and ETV was not statistically significant. A total of 11 patients (48 \%) experienced relapse. Most relapses occurred within 1 year after NA cessation. The cumulative relapse rate at 1 year, 2 years, and 5 years were $30 \%, 35 \%$, and $39 \%$, respectively. In contrast, $44 \%$ of patients were under control without NA administration.

\section{HBeAg-positive patients}

Thirty-eight (69 \%) patients received LMV and the remaining 17 (31\%) received ETV (Fig. 2). In patients who received LMV, 13 patients (34 \%) met the stopping criteria. Six (60\%) of 10 patients who consented to stop LMV maintained remission. The mean \pm SD of treatment duration until discontinuation was $44 \pm 23$ (min-max: 15-86) months. In 4 relapsers, 2 achieved remission afterwards, while 2 restarted ETV. Only 2 of 17 who received ETV met stopping criteria, and both continued ETV treatment. Finally, 4 patients ( $40 \%)$ relapsed. The 1-year, 2-year, and 5 -year cumulative relapse rates were $20 \%, 30 \%$, and $30 \%$, respectively, whereas $15 \%$ of patients were under control without NA administration.

\section{Predictive factors for meeting the stopping criteria}

HBeAg-negative patients were more likely to meet the stopping criteria than HBeAg-positive patients $(95 \%$ vs. $27 \%, P<0.001$, Fig. 3). We analyzed the predictive factors for meeting the stopping criteria in $\mathrm{HBeAg-positive}$ patients. Multivariate analysis revealed lower serum HBV-DNA level as the only predictive factor $(P=0.02)$. The proportion of patients who met the stopping criteria was $42 \%(10 / 24)$ in those with serum HBV-DNA of 7.6

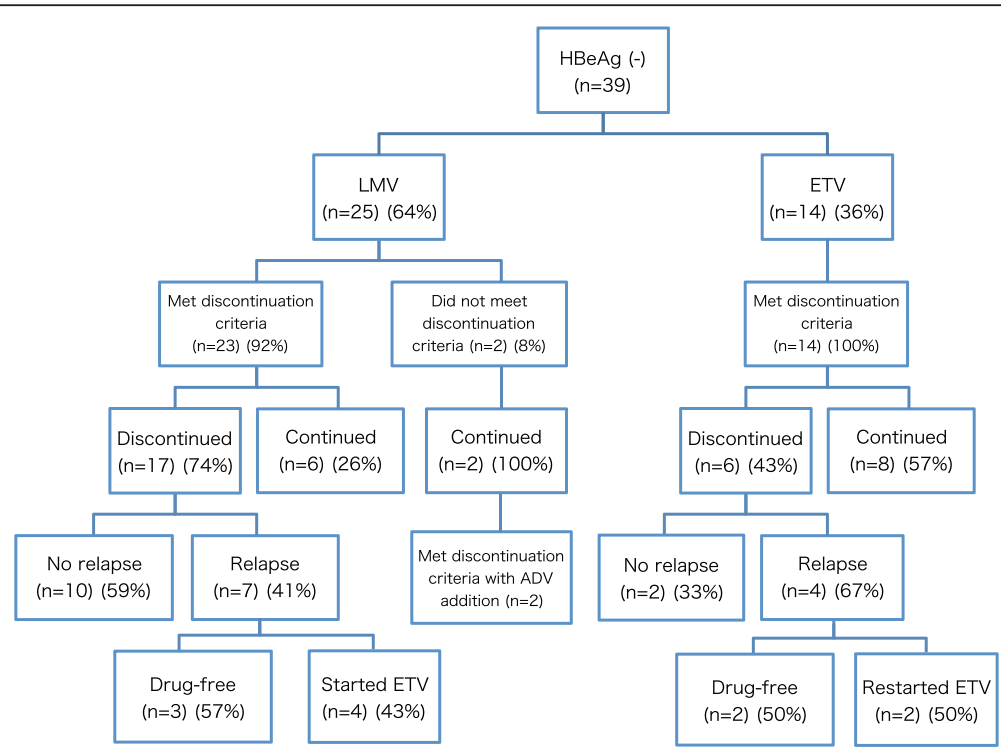

Fig. 1 Flow chart of HBeAg-negative patients. LMV: lamivudine, ETV: entecavir, ADV: adefovir 


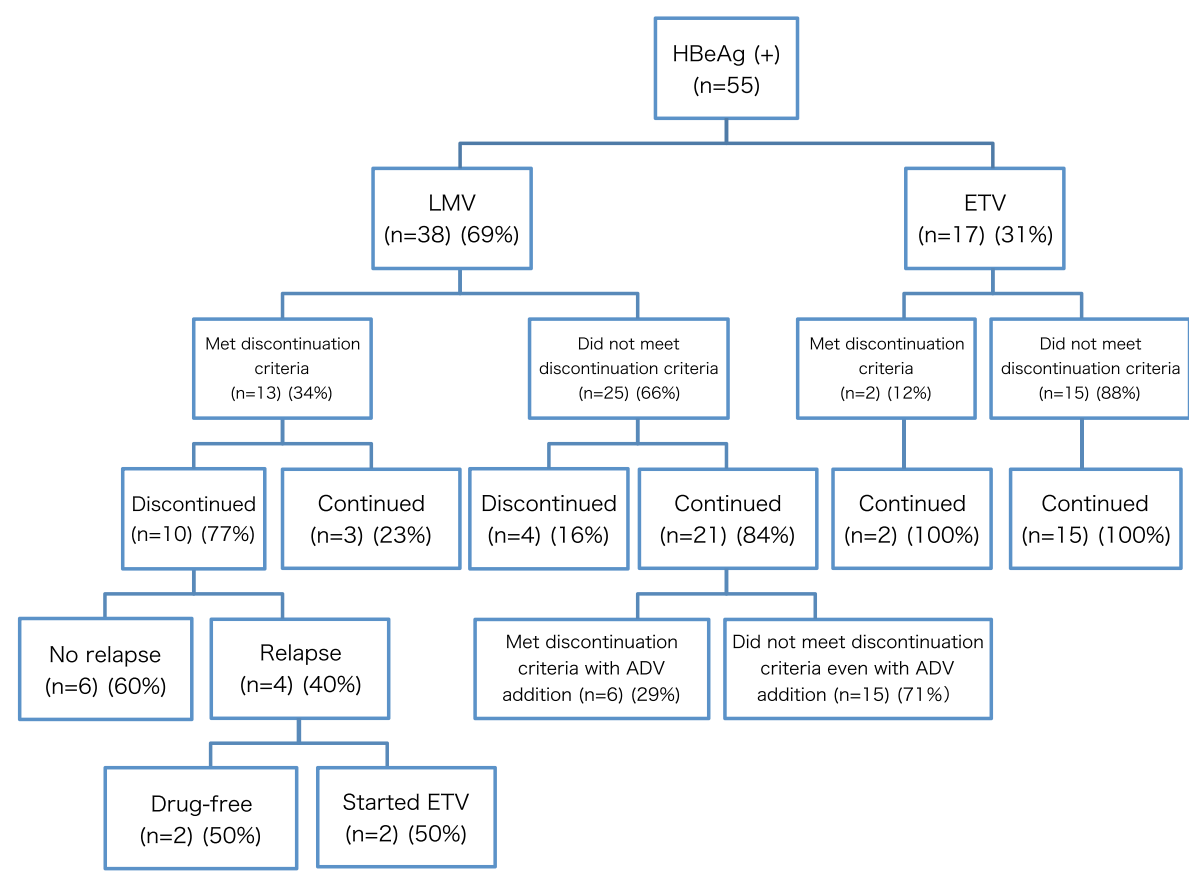

Fig. 2 Flow chart of HBeAg-positive patients. LMV: lamivudine, ETV: entecavir, ADV: adefovir

$\log$ copy/mL or less, whereas it was $15 \%(5 / 31)$ in those with serum HBV-DNA higher than $7.6 \log$ copy/mL.

\section{Predictive factors for relapse}

A total of 15 (45\%) among 33 patients who discontinued NA treatment relapsed, while the remaining 18 (55\%) maintained remission. We analyzed the baseline variables associated with relapse. Multivariate analysis demonstrated that serum ALT was the only predictive factor for relapse. Relapse rate was $50 \%(2 / 4), 71 \%(10 /$ $14)$, and $20 \%(3 / 15)$ in patients with ALT < 100, 100199 , and $\geq 200 \mathrm{IU} / \mathrm{mL}$, respectively. The patients with $\mathrm{ALT} \geq 200 \mathrm{IU} \mathrm{mL}$ were more likely to maintain remission (Fig. $4, P=0.02$ ).

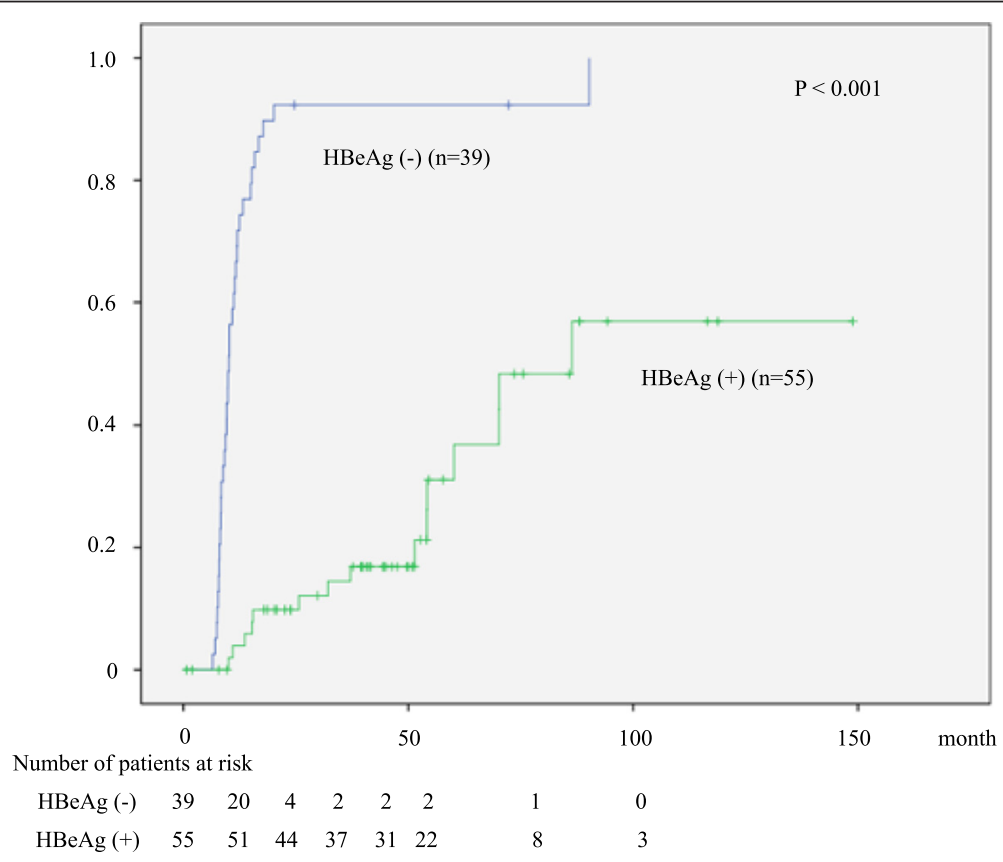

Fig. 3 Cumulative rate of satisfying NA stopping criteria according to the HBeAg status 
Serum ALT elevated up to more than $500 \mathrm{IU} / \mathrm{mL}$ in 4 of 15 relapsers (27\%), however, none experienced decompensation.

\section{HBsAg disappearance}

Serum HBsAg disappeared in 7 patients (7.4\%), resulting in an annual $\mathrm{HBsAg}$ disappearance rate of $0.8 \% ; 1.4 \%$ and $0.4 \%$ for $\mathrm{HBeAg}$-negative and -positive patients, respectively. We analyzed the baseline factors associated with HBsAg loss. Serum HBV-DNA was the only predictive variable by multivariate analysis; HBsAg loss was observed in 5 of 15 patients (33\%) with serum HBV-DNA less than $6 \log$ copy/mL, while 2 of 79 patients $(3 \%)$ with serum HBV-DNA of $6 \log$ copy/mL or higher $(P=0.001)$. The accumulated HBsAg loss was observed more frequently in those with lower HBV-DNA (Fig. 5, $P=0.02$ ).

\section{HCC progression}

Five of 94 (5.3\%) patients progressed to $\mathrm{HCC}$, resulting in an annual HCC progression rate of $0.6 \%$ in both $\mathrm{HBeAg}$-negative and -positive patients. Age was the only predictive variable for $\mathrm{HCC}$ progression by multivariate analysis $(P=0.01)$. Only one of $74(1.4 \%)$ patients younger than 60 years progressed to HCC, whereas did 4 of $20(20 \%)$ patients aged 60 or older $(P=0.01$, Fig. 6). Four patients died, all of whom were $\mathrm{HBeAg-positive.}$ One died of HCC and the remaining 3 died of the diseases unrelated to the liver (pancreatic cancer, gastric cancer, and unknown).

\section{Discussion}

In approximately 9 years after initiating NA administration, $44 \%(17 / 39)$ of HBeAg-negative patients and $15 \%$ (8/55) of HBeAg-positive patients were under control without NA. In other words, more than half of $\mathrm{HBeAg}$ negative and most of $\mathrm{HBeAg}$-positive patients still need NA therapy, suggesting difficulty in stopping NA therapy.

In this study we adopted the APASL stopping recommendation [12]. Most of the HBeAg-negative patients (95\%) satisfied this stopping criteria, whereas only one forth of the HBeAg-positive patients (27\%) did. These results are in agreement with a study [15] reporting that seroconversion from $\mathrm{HBeAg}$-positive to $\mathrm{HBeAb}$-positive occurred only in $38 \%$ of $\mathrm{HBeAg}$-positive patients through 4 year-treatment of ETV. Multivariate analysis revealed that patients with lower serum HBV-DNA levels were more likely to meet the stopping criteria in concordance with the previous study [15]. Thus, patients with higher serum HBV-DNA will have difficulty to cease NA treatment once it started.

In $\mathrm{HBeAg-negative} \mathrm{patients,} \mathrm{the} \mathrm{cumulative} \mathrm{relapse}$ rate after discontinuation of NA therapy was $48 \%$ (11/ $23)$, which was comparable with the previous studies [9, 16-19]. Jeng et al. [19] evaluated off-therapy durability in 95 patients who discontinued ETV treatment according to the APASL stopping recommendation as we adopted. The cumulative 1-year relapse rate was $45.3 \%$. On the other hand, another prospectively study [20] enrolling 184 patients in which ETV was stopped according to the APASL stopping recommendation demonstrated an

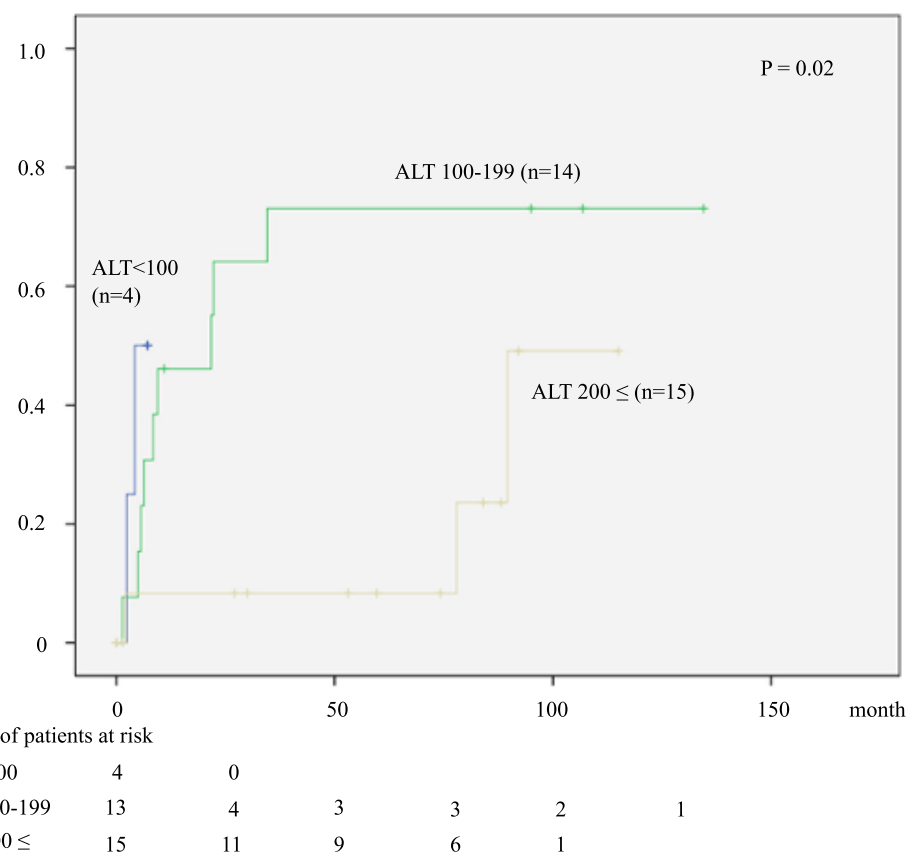

Fig. 4 Cumulative rate of relapse after NA discontinuation according to the serum ALT levels 


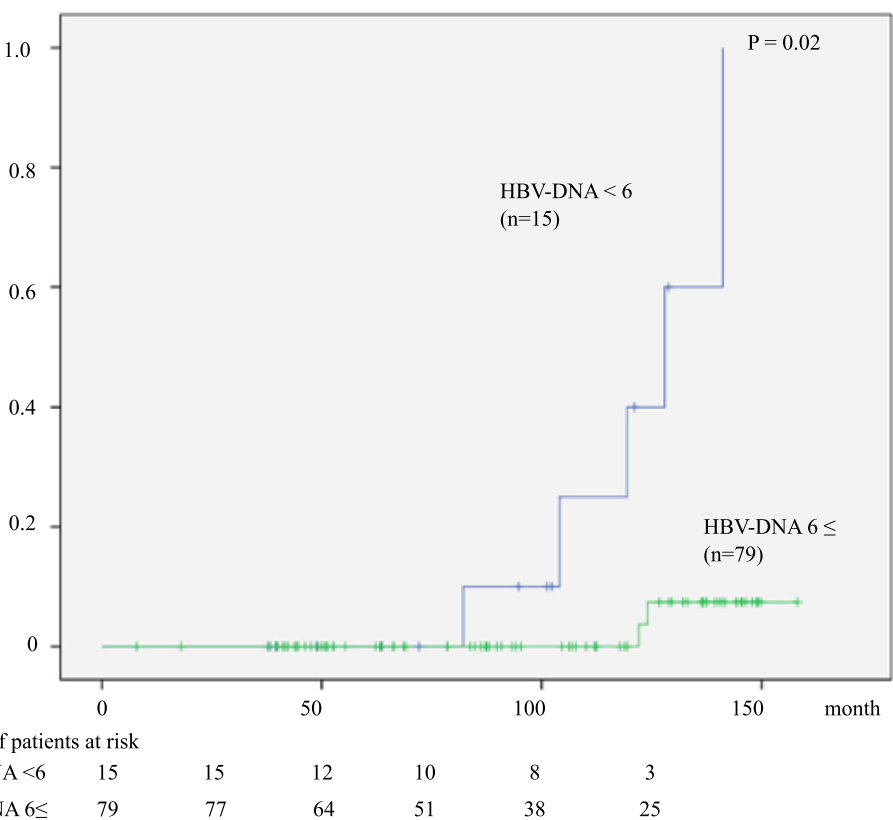

Fig. 5 Cumulative rate of HBsAg loss according to the viral load

exceptionally high cumulative 1-year relapse rate of 91.4 $\%$. Although reason for the discrepancy in the reported relapse rates is unclear, the differences in patients background and study design may be involved. The AASLD and EASL recommend long-term NA therapy until HBsAg seroclearance is achieved, however, this goal is unrealistic considering very low HBsAg seroclearance rate $(<1 \%$ per year [10]). The others and we showed that approximately half of the HBeAg-negative patients remained remission after cessation of NA therapy according to the APASL stopping recommendation. Thus, NA therapy can be stopped with proper monitoring.

In the $\mathrm{HBeAg}$-positive patients, cumulative relapse rate after discontinuation of NA therapy was $40 \%(4 / 10)$, which is in concordance with other studies ranging $29-77 \%$

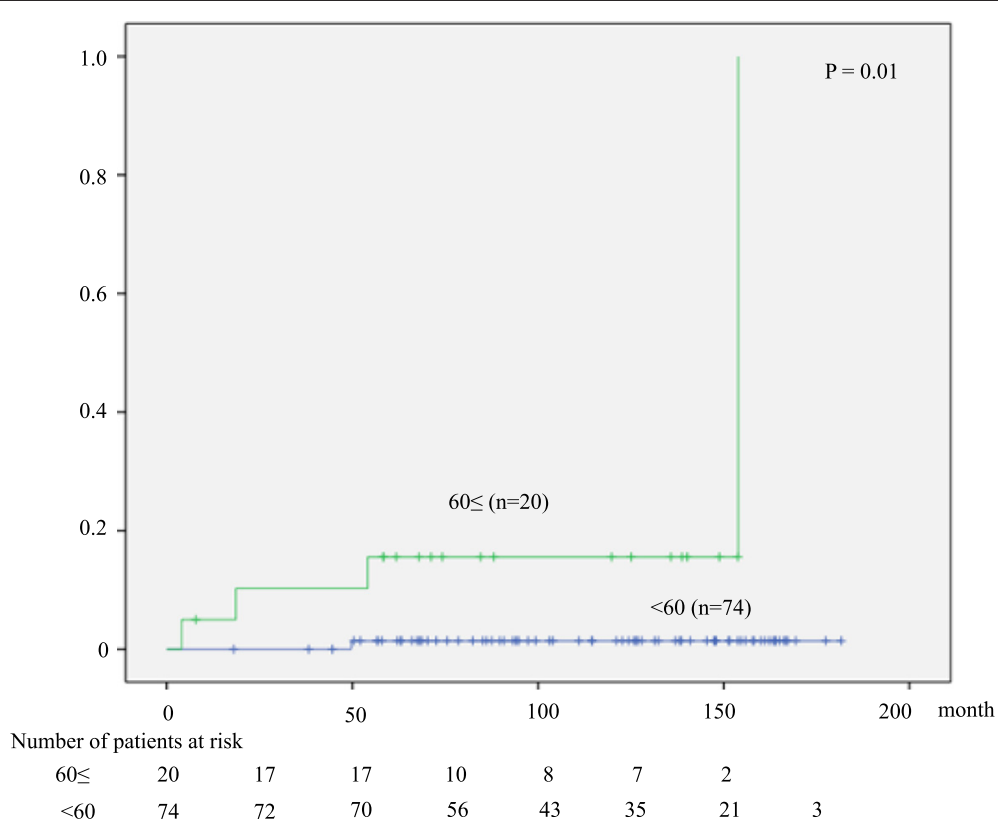

Fig. 6 Cumulative rate of HCC occurrence according to the age 
[5, 6, 8, 20-24]. According to a retrospective study of Song et al. analyzing $98 \mathrm{HBeAg}$-positive patients who stopped LMV therapy after HBeAg seroconversion, the cumulative relapse rates at 1 year and 2 years were $37.5 \%$ and $49.2 \%$, respectively [5].

Our study demonstrated that relapse was less frequently observed in patients with higher ALT levels in agreement with a previous study [6]. Patients with high ALT indicating strong immunological reaction against HBV may be on the transition state from immune clearance phase to low replicative phase in which relapse is relatively rare. Although lower baseline serum HBV-DNA $[5,6,19]$ and younger age $[9,25-27]$, and longer treatment duration $[5,27]$ were associated with lower relapse rate in other studies, we could not find these associations.

Four of 15 relapsers (27\%) underwent serum ALT flare above $500 \mathrm{IU} / \mathrm{L}$, however, they did not progress to liver failure. ALT flare with 10 times higher than normal upper limit was reported in up to $20 \%$ [2,3] of patients who discontinued NA treatment. We similarly observed ALT flare, but did not experience decompensation as previous studies $[9,19,20,22]$.

HBsAg disappeared at an annual rate of $0.8 \% ; 1.4 \%$ in HBeAg-negative and $0.4 \%$ in HBeAg-positive patients. These results are compatible with other studies [28-32]. Low baseline serum HBV-DNA was the only predictor for $\mathrm{HBsAg}$ disappearance in our study, in agreement with a previous study [33]. Kim et al. [33] revealed $0.33 \%$ annual HBsAg seroclearance rate by 6-year-follow-up of 5409 patients (two-thirds were $\mathrm{HBeAg}$ positive) receiving LMV or ETV therapy, and demonstrated baseline low HBVDNA, high ALT, HBeAg negativity, and absence of cirrhosis as predictors for HBsAg loss.

The progression to HCC was observed at an annual rate of $0.6 \%$ in both $\mathrm{HBeAg}$-negative and -positive patients, which results are in agreement with previous studies [33-36]. The decrease of HCC occurrence by long-term NA treatment is confirmed by a randomized study [1] and a meta-analysis [37]. The only predictive factor for HCC progression was age of 60 years or older, which is also reported in a previous study [36].

This study has limitations; the study was conducted in a retrospective manner in a single institution, and number of patients was small. Our patients predominantly consisted of genotype C. However, the data on offtreatment durability of NA's antiviral effect are still insufficient, and we believe our results provide important information.

\section{Conclusions}

Approximately half of the patients did not relapse after cessation of NA therapy in both HBeAg-negative and -positive patients. The relapsers did not experience decompensation.
Therefore, NA therapy could be discontinued with close monitoring if the APASL stopping recommendation is satisfied even in HBeAg-negative patients.

\section{Competing interests}

The authors declare that they have no competing interests.

\section{Authors' contributions}

NN collected patients' data, performed statistical analysis, and drafted the manuscript. TK participated in the design of the study, performed statistical analysis, and helped to draft the manuscript. SH, YA, KT, KA, KS, and TM participated in the collection of patients' data. All authors read and approved the final manuscript.

\section{Acknowledgments}

This study was supported in part by a research grant from the Ministry of Health, Labor and Welfare of Japan.

Received: 8 September 2015 Accepted: 9 March 2016

Published online: 17 March 2016

\section{References}

1. Liaw YF, Sung JJ, Chow WC, Farrell G, Lee CZ, Yuen H, Tanwandee T, Tao QM, Shue K, Keene ON, Dixon JS, Gray DF, Sabbat J. Lamivudine for patients with chronic hepatitis B and advanced liver disease. N Engl Med. 2004:351:1521-31

2. Honkoop P, de Man RA, Niesters HG, Zondervan PE, Schalm SW. Acute exacerbation of chronic hepatitis $B$ virus infection after withdrawal of lamivudine therapy. Hepatology. 2000;32:635-9.

3. Honkoop P, de Man RA, Niesters HG, Zondervan PE, Schalm SW. Acute exacerbation of chronic hepatitis $B$ virus infection after withdrawal of lamivudine therapy. Hepatology. 2000;32:635-9.

4. Santantonio T, Mazzola M, lacovazzi T, Miglietta A, Guastadisegni A, Pastore G. Long-term follow-up of patients with anti-HBe/HBV DNA-positive chronic hepatitis B treated for 12 months with lamivudine. J Hepatol. 2000;32:300-6.

5. Song BC, Suh DJ, Lee HC, Chung YH, Lee YS. Hepatitis B e antigen seroconversion after lamivudine therapy is not durable in patients with chronic hepatitis B in Korea. Hepatology. 2000;32:803-6.

6. van Nunen $A B$, Hansen BE, Suh DJ, Lohr HF, Chemello L, Fontaine $H$, Heathcote J, Song BC, Janssen HL, de Man RA, Schalm SW. Durability of $\mathrm{HBeAg}$ seroconversion following antiviral therapy for chronic hepatitis B: relation to type of therapy and pretreatment serum hepatitis $B$ virus DNA and alanine aminotransferase. Gut. 2003:52:420-4.

7. Ito $K$, Tanaka $Y$, Orito $E$, Hirashima N, Ide T, Hino T, Kumashiro R, Kato A Nukaya H, Sakakibara K, Mukaide M, Ito H, Sata M, Ueda R, Mizokami M. Predicting relapse after cessation of Lamivudine monotherapy for chronic hepatitis B virus infection. Clin Infect Dis. 2004;38:490-5.

8. Reijnders JG, Perquin MJ, Zhang N, Hansen BE, Janssen HL. Nucleos(t)ide analogues only induce temporary hepatitis $B$ e antigen seroconversion in most patients with chronic hepatitis B. Gastroenterology. 2010;139:491-8.

9. Liu F, Wang L, Li XY, Liu YD, Wang JB, Zhang ZH, et al. Poor durability of lamivudine effectiveness despite stringent cessation criteria: a prospective clinical study in hepatitis B e antigen-negative chronic hepatitis B patients. J Gastroenterol Hepatol. 2011;26:456-60.

10. Lok AS, McMahon BJ. Chronic hepatitis B: update 2009. Hepatology. 2009:50:661-2.

11. European Association For The Study Of The Liver. EASL clinical practice guidelines: Management of chronic hepatitis B virus infection. J Hepatol. 2012;57:167-85.

12. Liaw Y-F, Kao J-H, Piratvisuth T, Chan H, Chien R-N, Liu C-J, Gane E, Locarnini S, Lim S-G, K-H. H, Amarapurkar D, Cooksley G, Jafri W, Mohamed R, Hou J-L, Chuang W-L, Lesmana L, JD. S, Suh D-J, Omata M. Asian-Pacific consensus statement on the management of chronic hepatitis B: a 2012 update. Hepatology International. 2012;6:531-61.

13. Kang W, Park JY. When to stop nucleos(t)ide analogues treatment for chronic hepatitis B? Durability of antiviral response. World J Gastroenterol. 2014:20:7207-12.

14. Bedossa P, Poynard T. An algorithm for the grading of activity in chronic hepatitis C. The METAVIR Cooperative Study Group. Hepatology. 1996;24:289-93

15. Ono A, Suzuki F, Kawamura Y, Sezaki H, Hosaka T, Akuta N, Kobayashi M Suzuki Y, Saitou S, Arase Y, Ikeda K, Kobayashi M, Watahiki S, Mineta R, 
Kumada $\mathrm{H}$. Long-term continuous entecavir therapy in nucleos(t)ide-naive chronic hepatitis B patients. J Hepatol. 2012;57:508-14.

16. Fung SK, Wong F, Hussain M, Lok AS. Sustained response after a 2-year course of lamivudine treatment of hepatitis B e antigen-negative chronic hepatitis B. J Viral Hepat. 2004;11:432-8.

17. Paik YH, Kim JK, Kim do Y, Park JY, Ahn SH, Han KH, Chon CY, Lee KS Clinical efficacy of a 24-months course of lamivudine therapy in patients with $\mathrm{HBeAg}$ negative chronic hepatitis B: a long-term prospective study. J Korean Med Sci. 2010;25:882-7.

18. Hadziyannis SJ, Sevastianos V, Rapti I, Vassilopoulos D, Hadziyannis E. Sustained responses and loss of HBsAg in HBeAg-negative patients with chronic hepatitis B who stop long-term treatment with adefovir. Gastroenterology. 2012;143:629-36.

19. Jeng WJ, Sheen IS, Chen YC, Hsu CW, Chien RN, Chu CM, Liaw YF. Off-therapy durability of response to entecavir therapy in hepatitis B e antigen-negative chronic hepatitis B patients. Hepatology. 2013:58:1888-96.

20. Seto WK, Hui AJ, Wong WW, Wong GL, Liu KS, Lai CL, Yuen MF, Chan HL. Treatment cessation of entecavir in Asian patients with hepatitis B e antigen negative chronic hepatitis B: a multicentre prospective study. Gut. 2015;64:667-72.

21. Chien RN, Yeh CT, Tsai SL, Chu CM, Liaw YF. Determinants for sustained HBeAg response to lamivudine therapy. Hepatology. 2003;38:1267-73.

22. Dienstag JL, Cianciara J, Karayalcin S, Kowdley KV, Willems B, Plisek S, Woessner M, Gardner S, Schiff E. Durability of serologic response after lamivudine treatment of chronic hepatitis B. Hepatology. 2003;37:748-55.

23. Fung J, Lai CL, Tanaka Y, Mizokami M, Yuen J, Wong DK, Yuen MF. The duration of lamivudine therapy for chronic hepatitis B: cessation vs. continuation of treatment after HBeAg seroconversion. Am J Gastroenterol. 2009:104:1940-6.

24. Lee HW, Lee HJ, Hwang JS, Sohn JH, Jang JY, Han KJ, Park JY, Kim do Y, Ahn SH, Paik YH, Lee CK, Lee KS, Chon CY, Han KH. Lamivudine maintenance beyond one year after HBeAg seroconversion is a major factor for sustained virologic response in HBeAg-positive chronic hepatitis B. Hepatology. 2010;51:415-21.

25. Wang L, Liu F, Liu YD, Li XY, Wang JB, Zhang ZH, Park JY, Kim do Y, Ahn SH, Paik YH, Lee CK, Lee KS, Chon CY, Han KH. Stringent cessation criterion results in better durability of lamivudine treatment: a prospective clinical study in hepatitis B e antigen-positive chronic hepatitis B patients. J Viral Hepat. 2010;17:298-304.

26. Ha M, Zhang G, Diao S, Lin M, Sun L, She H, Kuan C, Shen L, Huang C, Shen W, Huang Z. A prospective clinical study in hepatitis B e antigen-negative chronic hepatitis B patients with stringent cessation criteria for adefovir. Arch Virol. 2012;157:285-90

27. Song MJ, Song do S, Kim HY, Yoo SH, Bae SH, Choi JY, Yoon SK, Paik YH, Lee JS, Lee HW, Kim HJ. Durability of viral response after off-treatment in HBeAg positive chronic hepatitis B. World J Gastroenterol. 2012;18:6277-83.

28. Chang TT, Lai CL, Kew Yoon S, Lee SS, Coelho HS, Carrilho FJ, Poordad F, Halota W, Horsmans Y, Tsai N, Zhang H, Tenney DJ, Tamez R, lloeje U. Entecavir treatment for up to 5 years in patients with hepatitis $B$ e antigen-positive chronic hepatitis B. Hepatology. 2010:51:422-30.

29. Gish RG, Chang TT, Lai CL, de Man R, Gadano A, Poordad F, Yang J, Brett-Smith H, Tamez R. Loss of HBsAg antigen during treatment with entecavir or lamivudine in nucleoside-naive HBeAg-positive patients with chronic hepatitis B. J Viral Hepat. 2010;17:16-22.

30. Zoutendijk R, Reijnders JG, Brown A, Zoulim F, Mutimer D, Deterding K, Petersen J, Hofmann WP, Buti M, Santantonio T, van Bommel F, Pradat $P$, Oo Y, Luetgehetmann M, Berg T, Hansen BE, Wedemeyer H, Janssen HL, Group VSS. Entecavir treatment for chronic hepatitis B: adaptation is not needed for the majority of naive patients with a partial virological response. Hepatology. 2011;54:443-51.

31. Hosaka T, Suzuki F, Kobayashi M, Seko Y, Kawamura Y, Sezaki H, Petersen J, Hofmann WP, Buti M, Santantonio T, van Bommel F, Pradat P, Oo Y, Luetgehetmann M, Berg T, Hansen BE, Wedemeyer H, Janssen HL, Group VSS: Entecavir treatment for chronic hepatitis B: adaptation is not needed for the majority of naive patients with a partial virological response. Hepatology 2011 54:443-45131. Hosaka T, Suzuki F, Kobayashi M, Seko Y, Kawamura Y, Sezaki H, Akuta N, Suzuki Y, Saitoh S, Arase Y, Ikeda K, Kobayashi M, Kumada H. Clearance of hepatitis B surface antigen during long-term nucleot(s)ide analog treatment in chronic hepatitis B: results from a nine-year longitudinal study. J Gastroenterol. 2013;48:930-41.

32. Kobayashi M, Hosaka T, Suzuki F, Akuta N, Sezaki H, Suzuki Y, Kawamura Y, Kobayashi M, Saitoh S, Arase Y, Ikeda K, Miyakawa Y, Kumada H.
Seroclearance rate of hepatitis B surface antigen in 2,112 patients with chronic hepatitis in Japan during long-term follow-up. J Gastroenterol. 2014:49:538-46.

33. Kim GA, Lim YS, An J, Lee D, Shim JH, Kim KM, Lee HC, Chung YH, Lee YS, Suh DJ. HBsAg seroclearance after nucleoside analogue therapy in patients with chronic hepatitis B: clinical outcomes and durability. Gut. 2014:63:1325-32.

34. Matsumoto A, Tanaka E, Rokuhara A, Kiyosawa K, Kumada H, Omata M, Okita K, Hayashi N, Okanoue T, lino S, Tanikawa K. Efficacy of lamivudine for preventing hepatocellular carcinoma in chronic hepatitis B: A multicenter retrospective study of 2795 patients. Hepatol Res. 2005;32:173-84.

35. Yuen MF, Seto WK, Chow DH, Tsui K, Wong DK, Ngai W, Wong BC, Fung J, Yuen JC, Lai CL. Long-term lamivudine therapy reduces the risk of long-term complications of chronic hepatitis B infection even in patients without advanced disease. Antivir Ther. 2007:12:1295-303.

36. Hosaka T, Suzuki F, Kobayashi M, Seko Y, Kawamura Y, Sezaki H, Akuta N, Suzuki Y, Saitoh S, Arase Y, Ikeda K, Kobayashi M, Kumada H. Long-term entecavir treatment reduces hepatocellular carcinoma incidence in patients with hepatitis B virus infection. Hepatology. 2013;58:98-107.

37. Sung JJ, Tsoi KK, Wong WW, Li KC, Chan HL. Meta-analysis: Treatment of hepatitis B infection reduces risk of hepatocellular carcinoma. Aliment Pharmacol Ther. 2008:28:1067-77.

\section{Submit your next manuscript to BioMed Central and we will help you at every step:}

- We accept pre-submission inquiries

- Our selector tool helps you to find the most relevant journal

- We provide round the clock customer support

- Convenient online submission

- Thorough peer review

- Inclusion in PubMed and all major indexing services

- Maximum visibility for your research

Submit your manuscript at www.biomedcentral.com/submit
) Biomed Central 